\title{
MERCURY CONTENT IN GARDEN SOILS OF URBAN AGGLOMERATION
}

\author{
H. DABKOWSKA-NASKRĘT \\ SZ. RÓŻAŃSKI
}

Received: 04/04/07

Accepted: 04/05/07

\author{
University of Technology and Life Sciences \\ Department of Soil Science and Soil Protection \\ 85-029 Bydgoszcz, Bernardyńska 6, Poland
}

*to whom all correspondence should be addressed: e-mail: dabkowska@utp.edu.pl

\begin{abstract}
The study report the degree of mercury contamination in garden soils of urban agglomeration and local sources of heavy metals emission like traffic and coal combustion. The urban soils have been compared with cultivated rural counterparts, developed on similar parent material. Mercury contents in urban garden samples showed two to nine fold increase over the rural areas and were in the range $52.2-293.9 \mu \mathrm{g} \cdot \mathrm{kg}^{-1}$ in surface horizons and $33.0-97.6 \mu \mathrm{g} \cdot \mathrm{kg}^{-1}$ in subsoils. The accumulation of mercury in topsoils suggests that atmospheric fall-out is the main source of contamination. The major fraction of $\mathrm{Hg}$ was bound to soil organic matter. It has been demonstrated that soil organic matter is significant sink for anthropogenic $\mathrm{Hg}$ in urban sandy soils.
\end{abstract}

KEYWORDS: mercury in soils, garden soils, urban soils, rural soils

\section{INTRODUCTION}

Mercury is a metal of major global environmental concern. Elevated level in soil is of considerable importance, due to its extremely high toxicity and mobility. As a result of its high volatility, elemental mercury can easily be transported and deposited far away from the source of emission [Alloway and Ayres]. Urban soils are known to have particularly high heavy metals contents, including mercury, from a variety of sources, including coal and oil combustion in electric power station, industrial plants and also from traffic. Urban garden soils may contain mercury from agrochemicals applied for plant protection. Garden soils composition has a direct influence on human health because of food production and also by possible ingestion or inhalation as suspended dust. Limited data exist regarding mercury concentration and accumulation in soils of urban agglomeration in Poland from gardens used for food production by their owners.

The aim of the study was to estimate the concentration of mercury in selected garden soils in urban area of Bydgoszcz agglomeration (northern Poland) and to characterize the role of soil organic matter in association of this metal.

\section{MATERIALS AND METHODS}

Soil samples originated from the gardens located close to the city center of Bydgoszcz (400.000 of inhabitants, without heavy industry, with a few local plants) were analyzed. The sites selected for the study were under typical, urban, diffuse sources of pollution and under the impact of traffic emission. Soil was sampled from the surface $(0-10 \mathrm{~cm})$ and subsurface horizons $(30-40 \mathrm{~cm})$. A total of 14 samples were collected. The urban soils have been compared with cultivated, rural soils developed on a similar parent material of glacigenic origin. For the rural soils, the samples were taken from cultivated fields ( 3 sites) within $50 \mathrm{~km}$ of the city. A map of the study area with the position of the samples is presented in Figure 1. 


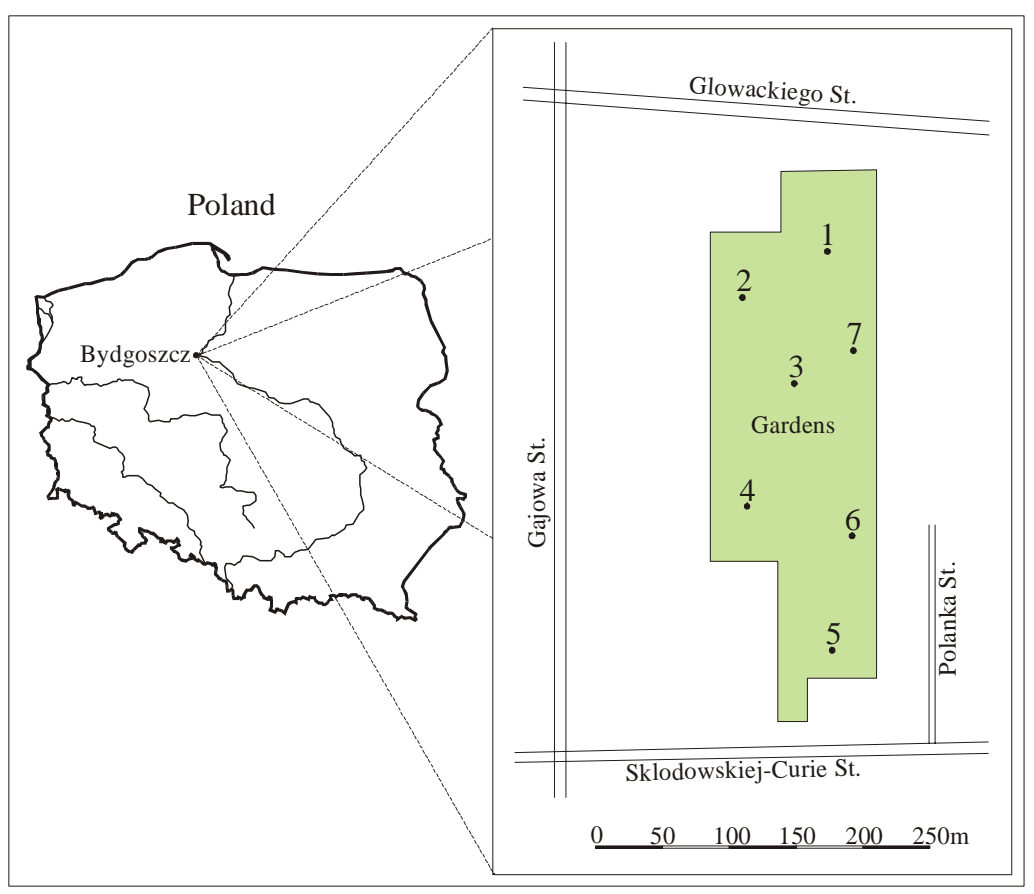

Figure 1. The study area and the position of sampling

The soil samples were air dried and sieved through a $2 \mathrm{~mm}$ stainless sieve. All laboratory tests followed standard methods: for soil $\mathrm{pH}$ determination, potentiometric method was used and sample: water ratio 1:2.5 (v:v) was applied. Organic carbon content was determined by wet combustion of soil samples with $0.4 \mathrm{M} \mathrm{K}_{2} \mathrm{Cr}_{2} \mathrm{O}_{7}$ solution. Cation exchange capacity was evaluated by the ammonium acetate extraction.

Total mercury contents were determined in solid soil samples using mercury analyzer AMA 254 (Slovakia) with a detection limit of $0.01 \mathrm{mg} \mathrm{Hg}$. Details on mercury determination are described elsewhere (Malczyk and Dabkowska-Naskręt, 2001). Organically bound $\mathrm{Hg}$ was estimated by the extraction of soils with $0.1 \mathrm{M} \mathrm{NaOH}$.

The quality control included reagent blanks to assess possible contamination, triplicate soil samples to check precision and certified soil material (Till 3) to test accuracy of the procedures. All the results were calculated on a dry-weight basis and are expressed in $\mu \mathrm{g} \cdot \mathrm{kg}^{-1}$ of soil.

\section{RESULTS AND DISCUSSION}

The results of the investigation are displayed in Table 1.

In all urban soils the content of organic matter is relatively high compared to rural soils, and ranged from 1.29 to $4.38 \%$ and from 0.84 to $3.21 \%$ of organic carbon in surface and subsurface horizons, respectively. The accumulation of organic matter is typical for urbanozems, due to the addition of plant residue, compost and other (Peltola and Astrom, 2003). Such enrichment in organic compounds has positive impact on cation exchange capacity of soils (Table 1). The comparison of urban soils with agricultural soils from rural area indicates higher cation exchange capacity of the studied garden soils from urban agglomeration.

The soil texture for urban samples was very similar to agricultural soils, with the exception of sample 8 - Table 1.

The total mercury levels in surface samples of urban soils ranged from 52.2 to $293.9 \mu \mathrm{g}^{\mathrm{kg}}{ }^{-1}$, and from 33.0 to $97.6 \mu \mathrm{g} \mathrm{kg}^{-1}$ in subsurface samples (Table 2).

The contents of mercury in rural, agricultural soils are distinctly different from that of the urban environment. Mercury contents in urban soils show two to nine fold enhancement over the rural values. For some urban soils the accumulation of mercury is even higher in surface horizons. The average value for the surface horizons in rural soils was $33,40 \mu \mathrm{g} \cdot \mathrm{kg}^{-1}$ and 
$24,82 \mu \mathrm{g} \cdot \mathrm{kg}^{-1}$ for subsurface samples. The content of $\mathrm{Hg}$ in most of the samples, and accumulation factors obtained through the comparison with the value of background level, indicates enrichment of this element in surface and subsurface horizons of garden soils (Figure 2).

Table 1. Physicochemical properties of soils

\begin{tabular}{|c|c|c|c|c|}
\hline $\begin{array}{c}\text { Sample } \\
\text { No }\end{array}$ & $\begin{array}{l}\text { Corg } \\
{[\%]}\end{array}$ & $\begin{array}{l}\text { Clay } \\
{[\%]}\end{array}$ & $\begin{array}{c}\mathrm{pH} \\
\mathrm{H}_{2} \mathrm{O}\end{array}$ & 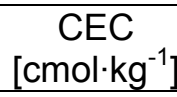 \\
\hline \multicolumn{5}{|c|}{ Urban soils } \\
\hline 1 & $\begin{array}{l}4.38^{*} \\
3.21^{* *}\end{array}$ & $\begin{array}{l}6 \\
5\end{array}$ & $\begin{array}{l}6.5 \\
5.8\end{array}$ & $\begin{array}{l}23.0 \\
14.3\end{array}$ \\
\hline 2 & $\begin{array}{l}3.30 \\
2.28\end{array}$ & $\begin{array}{l}5 \\
4\end{array}$ & $\begin{array}{l}6.9 \\
6.7\end{array}$ & $\begin{array}{l}36.0 \\
20.9\end{array}$ \\
\hline 3 & $\begin{array}{l}2.01 \\
1.26\end{array}$ & $\begin{array}{l}2 \\
5\end{array}$ & $\begin{array}{l}6.9 \\
6.9\end{array}$ & $\begin{array}{c}14.4 \\
4.9\end{array}$ \\
\hline 4 & $\begin{array}{l}2.04 \\
0.93\end{array}$ & $\begin{array}{l}6 \\
5\end{array}$ & $\begin{array}{l}6.7 \\
6.7\end{array}$ & $\begin{array}{c}16.6 \\
5.9\end{array}$ \\
\hline 5 & $\begin{array}{l}4.05 \\
1.71\end{array}$ & $\begin{array}{l}5 \\
8\end{array}$ & $\begin{array}{l}6.5 \\
5.9\end{array}$ & $\begin{array}{l}25.9 \\
11.9\end{array}$ \\
\hline 6 & $\begin{array}{l}3.75 \\
2.01\end{array}$ & $\begin{array}{l}6 \\
9\end{array}$ & $\begin{array}{l}7.1 \\
7.2\end{array}$ & $\begin{array}{l}45.3 \\
25.2\end{array}$ \\
\hline 7 & $\begin{array}{l}1.29 \\
0.84\end{array}$ & $\begin{array}{l}6 \\
3\end{array}$ & $\begin{array}{l}7.0 \\
6.9\end{array}$ & $\begin{array}{c}10.4 \\
5.8\end{array}$ \\
\hline \multicolumn{5}{|c|}{ Rural soils } \\
\hline 8 & $\begin{array}{l}0.97 \\
0.30\end{array}$ & $\begin{array}{l}15 \\
22\end{array}$ & $\begin{array}{l}6.5 \\
6.3\end{array}$ & $\begin{array}{c}6.8 \\
11.6\end{array}$ \\
\hline 9 & $\begin{array}{l}0.64 \\
0.55\end{array}$ & $\begin{array}{l}7 \\
5\end{array}$ & $\begin{array}{l}5.7 \\
5.8\end{array}$ & $\begin{array}{l}4.4 \\
3.9\end{array}$ \\
\hline 10 & $\begin{array}{l}0.85 \\
0.49\end{array}$ & $\begin{array}{l}3 \\
4\end{array}$ & $\begin{array}{l}4.8 \\
5.3\end{array}$ & $\begin{array}{l}3.0 \\
1.9\end{array}$ \\
\hline
\end{tabular}

* surface sample; ${ }^{* *}$ subsurface sample

The general pattern for all urban soils is a decrease of mercury contents with depth. Such a $\mathrm{Hg}$ distribution is reported by many investigators (Malczyk and Dąbkowska-Naskręt, 2001; Schuster, 1991; Haidouti,1991; Haidouti et al., 1985).

The sharp decrease in the $\mathrm{Hg}$ comes from atmospheric deposition in studied soils. A significant contribution to the pollution in the urban environment can have street dust.

There was no significant accumulation of mercury observed in rural topsoils compared to subsoils.

In the absence of Polish regulatory guidelines for mercury in soils, the upper limit of acceptable levels of $\mathrm{Hg}$ used in Great Britain and Belgium were applied for the evaluation of soil quality in the current study (Tack et al., 2005).

According to the above regulations the upper limit of mercury level for gardens and allotments is $1 \mathrm{mg} \cdot \mathrm{kg}^{-1}$. In the studied soils moderate pollution with $\mathrm{Hg}$ has been detected, however, mercury concentration doesn't exceed the upper limit recommended for agricultural soils. To asses the role of soil organic matter in $\mathrm{Hg}$ retention, $0.1 \mathrm{M} \mathrm{NaOH}$ was used for the extraction of organically - bound metal. The results of the study presented in Table 2 indicate very important function of soil organic matter as a sink of $\mathrm{Hg}$. This is in agreement with the results 
described by other authors (Malczyk and Dąbkowska-Naskręt, 2001). Mercury soil concentrations have been shown to be related to the organic matter. Processes that influence the transport of organic $\mathrm{C}$ may also influence the transport of $\mathrm{Hg}$ in soils profiles.

Natural organic matter, such as humic substances, contains a range of binding site types that can interact with $\mathrm{Hg}$ and other metals (Haidouti, 1991). According to Alloway and Ayres and Kabata-Pendias the retention of $\mathrm{Hg}$ occurs by valence - type ionic adsorption on soil organic matter and formation of covalence bonds with humic substances.

Table 2. Total mercury contents and fraction associated with soil organic matter in soils

\begin{tabular}{|c|c|c|c|}
\hline $\begin{array}{c}\text { Sample } \\
\text { No }\end{array}$ & $\begin{array}{l}\text { Total } \mathrm{Hg} \\
{\left[\mu \mathrm{g} \cdot \mathrm{kg}^{-1}\right]}\end{array}$ & $\begin{array}{l}\mathrm{OM}-\mathrm{Hg} \\
{\left[\mu \mathrm{g} \cdot \mathrm{kg}^{-1}\right]}\end{array}$ & $\begin{array}{c}\frac{\mathrm{OM}-\mathrm{Hg}}{\text { Total } \mathrm{Hg}} \\
{[\%]}\end{array}$ \\
\hline \multicolumn{4}{|c|}{ Urban soils } \\
\hline 1 & $\begin{array}{c}112.6 \\
78.3\end{array}$ & $\begin{array}{l}51.3 \\
46.2\end{array}$ & $\begin{array}{l}45.6 \\
59.0\end{array}$ \\
\hline 2 & $\begin{array}{c}293.9 \\
97.6\end{array}$ & $\begin{array}{l}153.4 \\
70.6\end{array}$ & $\begin{array}{l}52.2 \\
72.3\end{array}$ \\
\hline 3 & $\begin{array}{l}65.3 \\
33.0\end{array}$ & $\begin{array}{l}34.3 \\
24.8\end{array}$ & $\begin{array}{l}52.5 \\
75.1\end{array}$ \\
\hline 4 & $\begin{array}{c}104.8 \\
84.4\end{array}$ & $\begin{array}{l}29.3 \\
26.5\end{array}$ & $\begin{array}{l}28.0 \\
31.4\end{array}$ \\
\hline 5 & $\begin{array}{c}105.7 \\
75.0\end{array}$ & $\begin{array}{l}58.8 \\
39.6\end{array}$ & $\begin{array}{l}55.6 \\
52.8\end{array}$ \\
\hline 6 & $\begin{array}{l}98.1 \\
64.2\end{array}$ & $\begin{array}{l}26.2 \\
15.7\end{array}$ & $\begin{array}{l}26.7 \\
24.4\end{array}$ \\
\hline 7 & $\begin{array}{l}52.2 \\
40.0\end{array}$ & $\begin{array}{l}19.5 \\
16.8\end{array}$ & $\begin{array}{l}37.3 \\
42.0\end{array}$ \\
\hline \multicolumn{4}{|c|}{ Rural soils } \\
\hline 8 & $\begin{array}{l}48.6 \\
36.3\end{array}$ & $\begin{array}{l}35.4 \\
16.7\end{array}$ & $\begin{array}{l}73.7 \\
46.0\end{array}$ \\
\hline 9 & $\begin{array}{l}26.9 \\
16.0\end{array}$ & $\begin{array}{l}15.6 \\
6.5\end{array}$ & $\begin{array}{l}58.0 \\
40.7\end{array}$ \\
\hline 10 & $\begin{array}{l}24.6 \\
22.2 \\
\end{array}$ & $\begin{array}{l}14.4 \\
13.0 \\
\end{array}$ & $\begin{array}{l}58.3 \\
58.7\end{array}$ \\
\hline
\end{tabular}



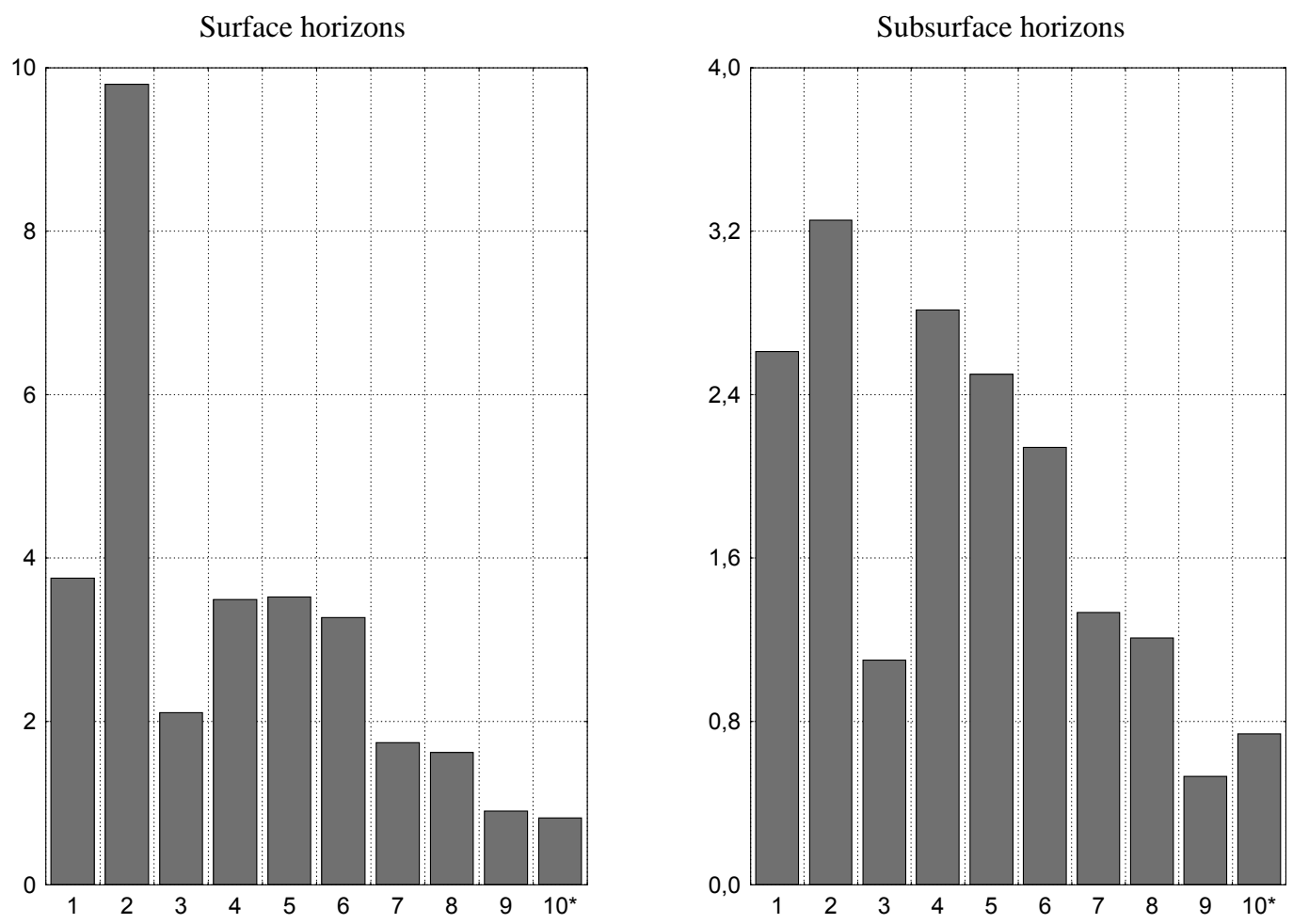

Figure 2. Accumulation factors of $\mathrm{Hg}\left({ }^{*}\right.$ sample site no)

\section{CONCLUSIONS}

In the area studied elevated contents of $\mathrm{Hg}$ were found in urban garden soils of similar genesis and texture. The distribution of mercury in surface and subsurface horizons suggests that atmospheric fall-out is the main source of contamination.

Mercury content was related to organic matter contents;

The above study proves that even in the absence of heavy industry, urban soils show significant increases in the concentration of $\mathrm{Hg}$.

\section{REFERENCES}

Alloway B.J. and Ayres D.C. (1997) The behavior of pollutants in the soil. In: Ayres D.C. (ed) Chemical principles of environmental pollution, Blackie, London, 395.

Haidouti C. (1991) Soil mercury pollution in the area surrounding the state oil refinery of Aspropirgos Greece, Catena, 18, 1-10.

Haidouti C., Skarlou V. and Tsouloucha F. (1985) Mercury contents of some Greek soils, Geoderma, 35, 251-256.

Kabata-Pendias A. (1999) The biogeochemistry of trace elements (in Polish), PWN, Warszawa.

Malczyk P. and Dabkowska-Naskręt H. (2001) Investigations on methods of total mercury determination in soils and biological material, Acta Agrophysica, 56, 165-175.

Peltola P. and Astrom M. (2003) Urban geochemistry: a multimedia and multielement survey of a small town in northern Europe, Environmental Geochemistry and Health, 25, 4, 397-419.

Schuster E. (1991) The behavior of mercury in the soil with special emphasis on complexation and adsorption processes - a review of the literature, Water, Air and Soil Pollution, 56, 667-680.

Tack F.M.G., Vanhaesebroeck T., Verloo M.G., Van-Rompaey K. and Van-Rastx E. (2005) Mercury baseline levels in Flemish soils (Belgium), Environmental Pollution, 134, 173-179. 